\title{
MEN NU LEVER VI I EN EROTISK KRISTID, ELLER HUR?
}

Frida Stéenhoff

Frida Stéenhoff (1865-1945) var på sin tid en välkänd dramatiker, essäist och rösträttskämpe. Hon var en skarp samhällskritiker på det socialpolitiska området, lika orädd som framsynt, och skrev om samkönad kärlek under en tid när ingen annan vågade. Det var Frida Stéenhoff som introducerade ordet "feminism" på svenska och kanske var hon också först med att använda ordet "antifeminism".

Stéenhoff stod i kontakt med Europas radikalaste skribenter i könspolitiska frågor. 1911 träffade hon Magnus Hirschfeld på en konferens, tidens främste forskare om homosexualitet och transfrågor. I ett entusiastiskt referat från tillställningen i tidningen Idun skrev hon: "Nu äntligen har vetenskapen beslutat genomtränga det mysterium, som kallas kärlek, och belysa dess blifvande, varande och verkande."2

Idag är mycket av det tankegods som väckte ett så våldsamt motstånd den gången allmänt accepterat. Annat är glömt - här och var framskymtar hos Stéenhoff, liksom hos så många andra vid den här tiden, inslag av rasbiologi. Stéenhoffs tänkande kretsade kring kärlekens samhälleliga villkor, ett ämne som låg i tiden, men som hon förstod på ett mer genomgripande sätt än andra. Enligt Elin Wägner var hon vid sidan av Ellen Key den som "modigast och skickligast behandlat de sexuella problemen" i Sverige. ${ }^{3}$ Men Ellen Keys befriariver handlade om heterosexualiteten och bara om den. Hon drog sig inte för att marginalisera den samkönade kärleken med hjälp av homofoba klichéer. Stéenhoffs projekt var radikalare, modernare om man så vill. Hon gjorde inte halt vid gränsen för den heteronormativa ordningen, utan vågade sig ut i det okända och tabubelagda, 
det som ingen vid 190o-talets början vågade skriva om på ett öppet och samtidigt bejakande sätt. Hon skrev om kärlek mellan kvinnor.

En bärande tanke hos Stéenhoff var att mäns och kvinnors samhälleliga villkor var så ojämlika, såväl inom som utom äktenskapet, att själva kärleken inte fick något livsrum. Kvinnornas villkor måste därför förbättras inte bara för deras egen skull, utan också för barnens och männens. Kärleken fick inte sättas under penningens ok. Det var en utgångspunkt för Stéenhoff, precis som det hade varit för de författare som gjorde rubriker under hennes egen ungdom.

Hon debuterade 1896 med Lejonets unge, ett drama som närmast framkallade panik i Sundsvall där det först sattes upp, berättar hennes biograf Christina Carlsson Wetterberg. ${ }^{4}$ Här kritiserades det ojämlika äktenskapet och här framfördes tanken att det är kärleken, och endast kärleken, som avgör om en relation är sedlig eller inte. Dramat antyder också möjligheten av barnbegränsning, vilket var synnerligen kontroversiellt.

I essän Feminismens moral (1903) gick Stéenhoff till motattack mot dem som hade beskyllt dramat och henne själv för sedeslöshet. "Den regerande moralen dyrkar styrkan", skrev hon. "Den är krypande och artig mot de mäktiga - hård och obarmhärtig mot de små och svaga. Den gillar det som lyckas - ibland till och med de gröfsta brott." Den gängse moralen "har plats för lagliga förbindelser, för celibat och för prostitution, men ingen plats för kärleken.” Den har en moral för män och en annan för kvinnor. "Den försvarade åsikten, att en ogift moder skulle så godt som trampas ned, under det en ogift fader icke skulle på något sätt oroas.”

Mot detta ställer Stéenhoff feminismens moral som bygger på rättvisa, kunskap och omsorg. "Kvinnornas flertal sträfva som trälar från vaggan till grafven.” De arbetar för sin egen försörjning, samtidigt som de föder och vårdar barnen, vilket ofta ställer dem i ett beroendeförhållande till männen. Den lösning hon ser är att kvinnorna blir ekonomiskt oberoende, att barnens försörjning görs till en angelägenhet för hela samhället och att kvinnorna får fulla medborgerliga rättigheter. Barnens väl och ve ska inte få bestämmas av fädernas godtycke och barn som är födda utanför äktenskapet måste ges samma möjligheter som andra barn. ${ }^{5}$ 
I essän Den reglementerade prostitutionen kritiserade Stéenhoff den samhälleliga hanteringen av prostitutionen. Kvinnor som sålde sex var ålagda att regelbundet inställa sig för hälsokontroll - syftet var att försöka få bukt med de grasserande könssjukdomarna - men männen, sexköparna, slapp undan denna förnedrande procedur och kunde alltså ostörda föra smittan vidare. Stéenhoff fann systemet lika orättvist som irrationellt. Prostitution var för henne en fråga om social och ekonomisk orättvisa, om mäns privilegier och kvinnors vanmakt. I essän Hvarför skola kvinnorna vänta? (1905) är det rösträtten som avhandlas och i Krigets herrar - fredens herrar (1915) skriver hon om fredsfrågan. För att nu nämna några av de texter som var brinnande aktuella när de skrevs. ${ }^{6}$

Men här ska det handla om Stéenhoffs skildringar av kärlek mellan kvinnor, ett motiv hon återkom till gång på gång. Hon skrev inte mindre än fem texter som handlar om detta, två som publicerades och tre som av olika skäl förblev otryckta. Tillsammans spänner de över en tidsrymd av tre decennier, alltså hela den tidsperiod som denna bok handlar om.

\section{Det moderna Lesbos}

När Lejonets unge publicerades blev Frida Stéenhoff omedelbart kontaktad av Ellen Key, hon som skulle komma att bli (hetero)kärlekens prästinna. Här hade en ung kvinnlig författare skrivit ett drama om en kvinna som går sin egen väg, både inom (hetero)kärleken och som konstnär, och här framställdes den olegaliserade förbindelsen som alternativet till den ojämlika äktenskapliga institutionen. Victoria Benedictsson, Alfhild Agrell och Anne Charlotte Leffler hade visserligen varit lika kritiska mot den rådande ojämlikheten som Stéenhoff var, men de äldre författarkollegernas berättelser hade för det mesta slutat i disharmoni och Lejonets unge har ett lyckligt slut. Äntligen! De älskande får varandra utan att först ha gått till prästen. Dubbelmoral och trångsynthet får ge vika. Kärleken segrar. Ellen Key jublade.

Såväl dramats huvudperson som dess författare hade drag gemensamma med den framtidskvinna som Ellen Key ständigt åter- 
kom till, även om Stéenhoff var ordentligt gift med sina barns far. Hennes man var dessutom läkare, ett yrke som brukade ges utopiska dimensioner i den naturvetenskapligt influerade samhällssyn som Key bekände sig till. Hon gav den unga debutanten ett välkommet handtag genom att skriva en uppskattande artikel om Lejonets unge och hon lånade titeln till ett av sina mest kända verk ur dramats text, nämligen "barnets århundrade". Vänskapen mellan de båda kvinnorna växte fram snabbt. Den byggde på att de i mångt och mycket hade en likartad syn på tidens problem och att de uppfattade varandra som kamrater i kampen för en ny könsordning. Breven har också en varmt personlig ton, som vittnar om mer än bara ett kollegialt intresse. Det tycks ha funnits ett slags attraktion mellan dem - som gick i båda riktningarna. 26/4 1899 skrev Key:

Du skref så rart till mig så att jag fick tårarna i ögonen och ville krama dig emedan du är som du är - en så sällsynt vacker människa! (innantill och utantill förstår du!) Jag har blifvit rikare genom att vi hafva kommit hvarandra nära. Tack!?

Vänskapen skulle komma att bestå livet ut även om det ibland gnisslade rejält mellan dem. De hade visserligen många gemensamma idéer, men Stéenhoffs radikalitet var mer grundad i det vardagsverkliga och könspolitiskt pekade den en i annan riktning. Hon beskrev sitt förhållande till Key så här: "vi ha olika meningar i alla frågor af vigt. Alla mina böcker ha innehållit opposition mot E.K. - inte för att hon är för hänsynslös utan för lite."

Vad gäller samkönad kärlek var Key, som sagt, allt annat än nytänkande. Helst ville hon inte befatta sig med frågan över huvud taget och när hon gjorde det skedde det på ett avståndstagande sätt eller med hjälp av underliga kringmanövrer. ${ }^{9}$ Kanske hade Stéenhoff inte detta riktigt klart för sig i början av deras bekantskap, för i slutet av 1890-talet skickade hon ett manuskript till Key med den uppseendeväckande titeln "Det moderna Lesbos". Stéenhoff hade då redan hunnit publicera två böcker och en tredje var på väg, men nu tvekade förläggaren. ${ }^{10} \mathrm{I}$ ett brev till Key daterat 27 november 1899 klagar Stéenhoff över detta: 
Få se om jag får ut någon bok mer! W. \& W. ha haft mitt sista manuskript i en och en half månad och ännu ej bestämt sig om de vilja ge ut det. Deras sista bref innehöll farhågor för en möjlig gifven storm, kanske åtal, hvarför jag måste låta sända luntan till min svåger juristen. Han har emellertid telefonerat att jag har ingenting att frukta, enligt hans åsigt. ${ }^{11}$

Stéenhoff tycks ha förväntat sig att hon i denna sak skulle få stöd av sin stridbara väninna, som hon ju hade fått i så mycket annat, men här högg hon i sten. Key blev förfärad. Den 17 december skrev Key:

Och ditt drama! Jag blef onekligen orolig öfver ämnet. Ty ehuru jag är lika viss som om jag läst det, att du behandlar ämnet med all finhet - det är ett frånstötande ämne ehuru kanske just ett som behövde röras vid? Ty jag tror att just kvinnoemancipationen, med sin ringaktning af moderskap och äktenskap, för vissa sådana abnormiteter med sig - åtminstone har jag sett många "erotiska" vänskapslidelser mellan ogifta kvinnor; ej alla sinnliga men med all förälskelsens svartsjuka, oro etc ... På mig [väcker (?)] allt sådant endast ilska - men jag är ju icke diktare, med blick för de sekundära problemen, utan Erosdyrkare med blick endast för den stora helsan och det största problemet: mans och kvinnas harmoniska enhet. Att en diktarblick som din även i detta kan finna djupt psykologiskt intresse kan jag förstå; ty det är ett stort psykiskt mysterium, liksom jättebläckfisken och andra odjur i naturen! ${ }^{12}$

Dessa rader innehåller som synes ett hopkok av föreställningar om kärlek mellan kvinnor, för vilket den mest adekvata termen nog är "homofobi", det vill säga en intensiv, irrationell rädsla för homosexualitet. Kanske också "feministfobi" för det är ju kvinnorörelsen som antas vara roten till det onda. Key känner ilska inför tanken på passioner mellan kvinnor, förskjuter fenomenet till kulturens marginaler och släpper slutligen fram skräckfantasiernas jättemonster. Ändå menar hon att ämnet behöver tas upp. Det får bara inte ske på ett så accepterande sätt. Kort sagt: dramat måste heterosexualiseras. 
När Ellen Key sedan läste texten, blev hon så orolig och bekymrad att hon tog sin väninna Anna Lindhagen till hjälp för att få mera kraft bakom sina kritiska ord. Långfredagen 1900 kommenterade hon i ett brev till författaren "Det moderna Lesbos" så här:

tack för att jag fick läsa det $\mathrm{i}$ hög grad intressanta dramat. Det var ju inte indiskret att jag äfven lät Anna Lindhagen läsa det? Vi voro båda eniga i att vi voro glada att det icke kommit ut som det nu är! Ty du har gjort det* så på alla sätt abnormt att det nästan bara träffar sjukdomarne - läkarens område - mer än lifvet - diktarens!

* d.v.s. dessa - alla personerna!!

Orden i fetstil är inskjutna i texten efteråt. De tycks vara ditskrivna i syfte att mildra det hårda omdöme som ges. Ändå menar Key att det skulle kunna gå att få till ett i hennes tycke acceptabelt diktverk av det hela, men då måste tendensen förändras rejält. Den samkönade kärleken måste marginaliseras och heterosexualiteten överordnas. Bort med handeln med den unga kvinnan, bort med "den galne karlens moment och få in på scenen den friske, starke unge mannen istället!!" utbrister Key i brevet. Den "galne karlens moment" syftar gissningsvis på att det kan ha funnits en manskaraktär i pjäsen som var så hemsk att han dödade kvinnans tro på heterokärleken, medan "den friske, starke unge mannen" är den som ska återställa heterosexualiteten som norm. Det glödheta ämnet måste hållas på armlängds avstånd. Och helst längre bort än så. Inte ens vänner som dessa två kunde alltså tala om samkönad kärlek på ett öppet och värdeneutralt sätt. ${ }^{13}$

I sitt svarsbrev 21/4 1900 säger sig Stéenhoff visserligen vara tacksam för de goda avsikter som hon antar ligger till grund för Keys kritik, men samtidigt försvarar hon sin text: "arbeta om den har jag ingen lust till, därför får den ligga. Kanske man efter min död öfverser med dess tekniska brister." Hon tror att framtiden kommer att ge henne rätt. "Inom tio år finns det en hel litteratur i romanens ämne!" Hundra år senare skulle hon få vetenskapligt stöd för den tanken. Författarna till Sympatiens hemlighetsfulla makt (1999) förlägger homosexualitetens mediala genombrott i Sverige till just dessa år. ${ }^{14}$ En 
sökning i DN:s digitala arkiv bekräftar deras iakttagelser. Själv gjorde Stéenhoff sitt bästa för att bidra till en sådan attitydförändring.

Manuskriptet till "Det moderna Lesbos" finns inte längre kvar. Kanske förstördes det av författaren, kanske av någon annan. Den samkönade kärlekens historia är kantad av brända brev och förstörda manuskript. Men författaren släppte inte ämnet bara för att Key och bokförlaget blev förskräckta - "ämnet kan jag ändå inte komma ifrån", konstaterade hon i svarsbrevet. "Tyck inte att jag är tjurig och enveten öfver höfvan som håller på mitt. Håll af mig ändå!” Så sammanfattar hon sin reaktion på Keys kritik.

Stéenhoff hade en modernare uppfattning än Key och var bättre orienterad i ny forskning på området än den äldre väninnan. Kanske hade hon rentav läst Magnus Hirschfelds radikala tidskrift Jahrbuch für sexuellen Zwischenstufen ("Årsbok för sexuella mellanstadier"), som utkom med sitt första nummer 1899, alltså samma år som "Det moderna Lesbos" tillkom. Jahrbuch für sexuellen Zwischenstufen var en tvärvetenskaplig tidskrift som kom att förändra synen på hbt-frågor inom forskningen och leda fram till att homosexualitet så småningom avkriminaliserades i flera länder. Stéenhoffs svarsbrev skvallrar om besvikelse över Keys reaktion, men vänskapen kom ändå att bestå. Ett par år senare skulle Key - om än på ett ytterligt motsägelsefullt sätt - själv göra en insats i denna kontroversiella fråga.

\section{Ny kärlek}

1902 utkom i svensk översättning Ny kärlek. En bok för mogna andar av Elisabeth Dauthendey, med ett nyskrivet förord av Ellen Key. ${ }^{15}$ Romanen handlar mest om kärlek mellan kvinnor, men det låtsas Key inte om. Hon skriver uteslutande om heterosexualitet. Hon berättar att boken har utkommit i flera upplagor i Tyskland, att den redan har blivit översatt till andra språk och att den är en stor framgång för författaren.

Det var icke nog att den tongifvande kritiken hälsade boken med stort bifall och fint förstående; icke nog att en mängd kvinnor ge- 
nom enskilda bref sade författarinnan att hon uttalat deras känslor. Hon erhöll äfven ett betydelsefullare vittnesbörd om att den nya tiden nalkas sin fullbordan: ett stort antal bref från män sade henne nämligen, att äfven de börjat drömma den nya kvinnans drömmar om den nya kärlek, åt hvilken denna bok gifvit så djupt kända uttryck. ${ }^{16}$

Inte med ett ord nämner Key att boken till stor del handlar om kärlek mellan kvinnor och att det är just det som gör den så kontroversiell. I stället uppehåller hon sig vid de brevskrivande manliga läsarna vars vittnesbörd sägs vara "betydelsefullare" än kvinnornas - och ser i dem ett hopp om en ny och bättre (hetero)kärlek.

$N y$ kärlek är ett slags odyssé genom olika kärleksmöjligheter, kryddad med anspelningar på tidens idédebatt kring kärlekens biologiska och samhälleliga vara. Berättelsens huvudperson, Leonora, är ett exempel på den Nya Kvinnan - på tyska hette boken också Vom neuen Weibe und seiner Liebe. Ein Buch für reifer Geister. ${ }^{17}$ Hon har tröttnat på dubbelmoral, ojämlikhet och självgoda män och söker en annan och högre form av kärlek. "Men hvar finns den man, som kan gifva min törst detta rus och denna vederkvickelse? Han finns ej." ${ }^{18}$

Hon möter två män på sin livsresa. Den ene är en läkare som predikar blodets röst och naturens evangelium - här, som så ofta i tidens litteratur, sammanfaller "det naturliga" med heterosexualitetens och de tongivande männens intressen. Den andre är en halvt förlamad man som skänker henne själens men inte sexualitetens gemenskap, och det är honom hon väljer. Efter hans död ger hon sig sedan på nytt ut på kärleksjakt:

Och då jag för min del icke hoppades på mannen eller på barnet, - så hoppades jag på kvinnan.

Kvinnan förenad med kvinnan i en ren, stark kärlek, - till dess hon åter kan skänka sig åt mannen i sitt fullkomliga, nya väsende och sin fullkomliga, nya skönhet, hvilken skönhet hon endast för hans skull genom alla smärtor förvärfvat sig ur sitt djupaste lidandes grund. (62) 
Efter en tid möter Leonora den vackra och förmögna Nasti. De blir vänner, Leonora flyttar hem till henne och så en natt, när de står på balkongen och njuter av nattens skönhet, kommer det till ett avgörande. Passagen förtjänar att citeras i sin helhet:

"Icke heller du kan sofva", sade hon. - "Jag låg och längtade efter dig, såsom jag har längtat i veckor. - Har du icke känt det, du sköna, ljufva, härliga kvinna?” -

Och hon lade sina armar tungt om min hals -

Så föll hon på knä för mig, kysste mina fötter och omfattade mina knän.

"Var min, helt min, i gränslös ömhet! - Så vill jag njuta dig."

Och innan jag hunnit hämta mig från min förvåning, hade hon lyft mig på sina starka armar och burit mig öfver tröskeln in i mitt rum och lagt mig i min säng.

Nu öfverföll hon mig med en häftig, yrande ömhet, som jag icke genast kunde afvärja, då hon öfverrumplade mig så fullständigt oförberedd.

Ändtligen lyckades jag dock att befria mig från henne.

Fast och skonsamt tog jag henne på mina armar, ty jag hade medlidande med henne, och bar henne tillbaka in i hennes rum och stängde dörren emellan oss.

Då förstod hon mig och visste, att det icke var denna sapfiska kärlek, som jag ville; att därtill voro mina kvinnoinstinkter för hela och för sunda. (70-71)

Båda kan bära den andra från ett rum till ett annat. Inga späda violer precis. Den gemenskap Leonora söker är av känslomässig, inte av sexuell art. Så långt är heteronormen ohotad. Men författaren passar på att ta ut svängarna i skildringen av intimiteten mellan de båda kvinnorna så att det blir otvetydigt att det handlar om erotik - eller försök till - mellan mogna kvinnor. Längre än så var det nog inte möjligt att gå i tidens litteratur. Och om detta andas Key inte en stavelse. ${ }^{19}$

Leonora drar därefter vidare på sin livsresa och till slut hittar hon verkligen den kvinna hon så länge har sökt, nämligen sin egen fosterdotter. Också hon har gjort en odyssé i världen för att bli själv- 
ständig och finna sin egen väg. Nu är hon tillbaka och de båda kvinnorna kan återförenas i en innerlig, icke-erotisk kärlek:

Med helig hänryckning lät jag mitt hjärta berusas af denna varma kärleksström.

Den blomstrande unga kvinnan i sin egen skönhets fullhet och den mognade kvinnan i fullheten af sina erfarenheter och af det odödliga hoppet på lifvets tillkommande skönhet, - och dessa båda i stark tro på hvarandra och i ren kunskap om hvarandra, förenade med denna hängifvande kärlek, hvarmed blott kvinnor kunna älska, - var icke detta den sista lycka, som jag ännu hade att fordra af lifvet och för hvars sökande jag dragit ut i fjärran länder? (76)

Denna form av halvt incestuös kärlek mellan en äldre och en yngre kvinna skulle få ekon i många andra berättelser, varav det i svensk litteratur mest kända exemplet återfinns i Agnes von Krusenstjernas Pahlenserie. Men den skulle också, som vi snart ska se, dyka upp hos Frida Stéenhoff.

I Ny kärlek framstår den samkönade kärleken som interimistisk. Den Nya Kvinnan söker sig till kvinnan i väntan på den Nye Man som ännu inte existerar. Det saknas inte grund i romanen för Keys tal om den nya och bättre (hetero)kärlek som en gång ska komma, men det är inte där berättelsens fokus ligger utan i kritiken av den rådande sexualitetsordningen och i lovsången till relationer mellan kvinnor. $^{20}$

Om Ny kärlek som Key menar blev väl mottagen i sitt hemland, blev den desto mer förlöjligad i Sverige. Stéenhoff skrev därför en artikel till Dagens Nyheter där hon gick till bokens och Keys försvar. De frågor hon ville diskutera var: "Kan ett så allvarligt ämne som erotisk vänskap mellan kvinnor locka till skämt? Hvilka skäl finnas för att ogilla dylik vänskap?” Inte heller denna text publicerades. Ett par decennier senare skulle den i stora stycken gå rätt in i ett nytt drama om kärlek mellan kvinnor - som visserligen inte heller trycktes... Men mer om det längre fram.

Stéenhoff framhåller i sin artikel att samkönad kärlek är ett vik- 
tigt ämne och att hon själv "rätt mycket sysselsatt mig med dess psykologiska tema" i ett verk som "av konventionella hänsyn icke kunde blifva utgifvet". Det sista ströks sedan, förmodligen av henne själv. Grundtanken i texten är att kvinnokärleken är nödvändig så länge männen är som de är och att alternativet vore ensamhet och lidande. Den i sammanhanget kanske intressantaste passagen, även den överstruken, lyder:

Ty hvad kan erotiken mellan kvinnor blifva annat än ett sjukligt svärmeriförhållande - låt vara att det numera, utom i ytterst sällsynta fall, begränsar sig till det andliga området. Till skillnad från vanorna hos antikens folk, som icke hade vår fasa för perversitet $\mathrm{i}$ rent sexuell bemärkelse. ${ }^{21}$

Erotiken tonas ned, samtidigt som den samkönade kärleken försvaras. Man får hålla i minnet att texten är ett försvar mot angreppen på Key och den samkönade kärleken och att den därför kanske är mer anpassad till den rådande opinionen än andra texter Stéenhoff skrev. Dessa rader ersätts med orden "helt begränsad till det andliga området, således fullkomligt skild från perversitet i rent sexuell bemärkelse”. Den nya formuleringen är mindre värderande men också mindre konkret och därmed inte så brännande. Antikens homoerotik var vid den här tiden föremål för ett intensivt intresse bland författare som intresserade sig för samkönad kärlek. ${ }^{22}$ Att Stéenhoff nämner antiken antyder hennes kännedom om detta.

\section{Ett sällsamt öde}

1911 gav Stéenhoff ut novellsamlingen Kring den eviga elden, där de fem berättelserna behandlar olika former av kärlekspolitiska problem. Om man så vill kan man läsa boken som ett slags feministiskt svar på Strindbergs Giftasnoveller. Där han riktade udden mot kvinnorna och emancipationen, riktar hon sin kritik mot den ojämlika könsordning som berövar många kvinnor möjligheten att få sina kärleksdrömmar uppfyllda.

Den längsta och mest originella av novellerna i samlingen är den 
som heter "Ett sällsamt öde". Motivet presenteras redan genom berättelsens första rader:

Det cirkulerade genom världspressen för några år sedan ett avslöjande, som väckte uppmärksamhet. En framstående ämbetsman i Förenta staterna hade avlidit och först efter hans död blev för allmänheten bekant, att den avlidne i livstiden varit en kvinna. Han hade varit tvenne gånger gift.

Enligt den s. k. duplicitetens lag kom kort därpå, på andra vägar än pressens, till min kännedom en äktenskapshistoria, även den från Amerika, som måhända hade psykologiska likhetsdrag med den ovannämnda ämbetsmannens livsroman. ${ }^{23}$

Den första historien i citatet ovan är en framgångshistoria, men den andra, den som novellen arbetar vidare med, blir i Stéenhoffs gestaltning en tragedi. Om hon verkligen hade fått historien berättad för sig eller om hon diktade den fritt ur hjärtat kan vi inte veta, men klart är att den samtida sexologiska litteraturen kunde berätta mängder av liknande historier. ${ }^{24}$

Novellen börjar med att den elegante Mikael Ignace en dag kommer på visit hos Ethel. Tycke uppstår från första stund. Modern är bekymrad över att de inte vet något om den vackre främlingen, men även hon blir intagen av hans charm och snart kan det firas bröllop. Under festen håller en av gästerna ett tal om "att människan skapar själv sitt öde". Denna tanke dyker sedan upp vid alla kritiska skeenden i berättelsen.

Bröllopsnatten blir inte som bruden hade drömt att den skulle bli. I stället för att jublande ta sin brud i famnen är brudgummen nervös och börjar gråta.

- Är du sjuk eller är du olycklig? frågade hon lågt. Ångrar du dig?

- Om jag vore som jag borde, om jag vore hederlig, då skulle jag ångra mig, men jag kan inte. (48)

Mikaels svar är kryptiskt och det tar tid innan han förmår berätta hur det ligger till med hans könstillhörighet. Innan han gör det 
säger han: "Släpp inte den tanken, att du är fri - så förlåter du mig lättare." (49) Han tänker inte tvinga sig på henne, inte utnyttja de befogenheter som lagen gav mannen i äktenskapet. (Men som väl knappast var tillämplig i detta fall.) Och så släpper han bomben: "Jag har bedragit dig. Jag är en kvinna." (50) Vid dessa ord omvandlas Ethels förälskelse till motvilja och hon går in i ett psykosliknande tillstånd. Under hela hennes sjukdom och konvalescens finns Mikael vid hennes sida:

Hon såg i honom en sjukvårdare eller -vårderska, vilketdera kunde Mikael aldrig uppfatta. Kanske hon aldrig reflekterade över, om han var man eller kvinna. Behärskad av klädernas intryck kallade hon honom han, om hon någon gång var nödsakad att tala om honom. (52)

Berättaren gör samma sak. Även efter avslöjandet kallas han för Mikael. Ethel tillfrisknar så småningom och hennes motvilja börjar lägga sig. Hon ser att han trots allt är en god människa och börjar återfå sin sympati för honom. En kväll när de sitter i en liten båt ute på havet lägger Mikael upp årorna och börjar berätta sitt eget livs historia:

- Jag vågar säga, att jag icke är en dålig människa, oavsett detta. Han lade handen på sin panna. Det är ett fel här. Jag är defekt. Jag visste inte om det själv, förr än jag vid tjugotvå års ålder förälskade mig i en ung flicka, som i idealisk älsklighet var ett motstycke till dig. Efter flera månaders kvalfylld förälskelse, yppade jag för henne i ett exalterat ögonblick mina känslor. Hon visade mig sin avsky. Jag beslöt mig då för att dö och sköt mig en kula i huvudet. Här i vänstra tinningen gick kulan in. Att den icke dödade mig var alla en gåta. Sedan framsläpade jag tolv år av skamfylld och förtvivlad längtan. Jag ville älska och bli älskad, det var min förhärskande tanke. Då faller en dag mina ögon på en säregen levnadshistoria. En ansedd man hade avlidit och först efter hans död upptäckte man, att han var kvinna. Vad som brände sig med eldskrift fast i min själ var orden, att han levat $i$ ett lyckligt äktenskap. (56) 
En enda berättelse om en kvinnas lyckliga liv med en kvinna är det halmstrå hon finner i sin sorg; den ger henne mod att ikläda sig rollen som man och själv gå ut i världen för att söka kärlek hos en kvinna. Mikael berättar historien om sina förbjudna känslor när paret befinner sig i en båt ute på havet, alltså på tryggt avstånd från det sociala livet med dess trångsynta konventioner. Strindberg hade använt samma grepp i en av de Giftas-noveller som tar upp homosexualitet, nämligen den för sin tid så radikala "Den brottsliga naturen".25

Mikael skaffar sig en manlig identitet, och efter "en kort tid hade jag fått fullkomlig säkerhet i att röra mig, klädd som man". (56) Identitetsbytet sker alltså för att han äntligen ska få möjlighet att komma en kvinna nära. Han lever som man i många år, tills han slutligen, genom Ethel, möter kärleken. Hon kommenterar hans berättelse så här:

- Om du verkligen älskat mig, hade du ej haft hjärta att bedraga mig. Du hade då hellre försökt på ärlighetens väg.

- Jag drevs att handla som jag gjorde. Jag kunde ej annat. Tror du annars, att jag skulle trotsat alla de själsmarter jag utstått? Jag har levat som i ett helvete. Men om det gällt mitt liv, jag kunde ej annat. Jag måste försöka. (57)

Ethel förebrår honom alltså för att han inte har varit ärlig - han kunde ju ha försökt närma sig henne utan förklädnad. Men Mikael vill själv skapa sitt öde, han som andra, och han drivs till det av ett starkt inre tvång. Han är en ädel karaktär, och efter avslöjandet så osjälvisk att han blir självutplånande.

De kyssar vi växlade som förlovade är de enda smekningar, som skall ha förmildrat min ensamhet, när jag dör. Tack för dem, Ethel! Det är ingen skam för dig. Du visste inte då, vilken vidrig, olycksdömd varelse jag var. Men jag är dock ganska ren och oskyldig. Sådana ord låter kanske underliga i min mun, men sanningen är, att jag är oerfaren som ett nyfött barn. Jag har ingen vetskap om det jag längtar efter, jag förstår inte, vad jag vill, jag förstår inte mig 
själv. Allt är mig en gåta. Jag är som en blind slav, som en piska driver fram på en väg, som han inte känner. (57)

Här finns inga teorier om dekadens, degeneration, drogmissbruk eller något annat otrevligt som samkönad kärlek brukade förknippas med. Mikael har inte utvecklats till det han är genom ett osunt och sexuellt expansivt leverne, vilket annars var en standardteori om homosexualitetens uppkomst. Känslorna kommer från hans inre. De är skapade av naturen. Han är "ren". Mikael klandrar sig själv, men berättaren säger aldrig något förklenande om honom.

Efter båtturen förändras relationen mellan dem. Mikael beslutar sig i tysthet för att dö, samtidigt som Ethels sympati och beundran för maken växer. Mikael sätter Ethel i förbindelse med en man, en konstnär, i passande ålder och när han tror att de två har funnit varandra i kärlek tar han livet av sig genom att kasta sig i havet från en hög klippa. Precis som Sapfo, enligt legenden, en gång gjorde i sorg över en förlorad kärlek. En legend man visserligen inte ska tro på, men ändå. ${ }^{26}$

Ethel gör tyst för sig själv en jämförelse mellan Mikael och konstnären, som på alla sätt faller ut till makens fördel: "Vilka kontraster dessa varelser, tänkte Ethel. Mikael så säker, behärskad, orubblig, som gick han sin väg fram på order från ett oblidkeligt öde, utan att se varken till höger eller vänster.” Det är Mikael som är den verklige Mannen av de två och det är han som är den trogne, ja som är den rätte Älskaren. Om det nu inte hade varit för det där med könet...

Vid Mikaels död uppdagas det att han har en kvinnas kropp. Det blir skandal och Ethel förvandlas själv till "en brännmärkt person". Hon är plötsligt lika förtvivlat ensam som Mikael varit och börjar arbeta på den asyl där hon själv en gång var patient. En av sköterskorna där berättar vad som förväntas av henne som sköterska. Och det är hennes ord som får avsluta novellen:

- Vi måste söka ge patienterna mera tro på den egna kraften, mera hopp, mera insikt om den fria viljans betydelse.

Ett minne rann Ethel i hågen, det vackra talet från hennes bröllopsfest. 
- Jag förstår, svarade hon vemodigt, människan skapar själv sitt öde. Hon är sin egen lyckas smed.

- Just så, nickade översköterskan, under det hon förde ut ett par små underliga barn på gräsmattan i solskenet. (63-64)

Mikael hade ju försökt att skapa sitt eget öde. Hans liv fick visserligen ett tragiskt slut, men fram till sin död kämpade han för att leva sitt liv i enlighet med sina känslor. Själv beskrev han sig som defekt, men det är inte den bild novellen ger av honom. Han är en vacker man med ett vinnande sätt, en hederlig människa, en framgångsrik yrkesman och en lika trofast som passionerad älskare. I en bättre värld skulle Mikael ha funnit den kärlek han sökte och levt ett gott och samhällsnyttigt liv. ${ }^{27}$

\section{Kärlekens rival}

Året därpå, 1912, var det dags för ytterligare en text om samkönad kärlek, nu i det lite större formatet, nämligen Kärlekens rival. Den tycks ha blivit en av Stéenhoffs mest spelade pjäser. ${ }^{28}$ "Liksom många andra - kanske de flesta - av Frida Stéenhoffs arbeten kom Kärlekens rival som första inlägg i en fråga, vilken man i Sverige ännu icke var beredd att diskutera." Det menar hennes första biograf, Beatrice Zade. ${ }^{29}$ Det allra första inlägget var det nu inte, men tidigt var det absolut.

Ämnet var rykande aktuellt när Stéenhoff skrev dramat. 1907 hade den så kallade Eulenburgskandalen briserat i Tyskland, där flera av kejsar Wilhelm II:s närmaste medarbetare beskylldes för homosexualitet. Detta blev en mediahändelse av samma omfattning som Wilde-rättegångarna hade varit i England ett decennium tidigare. Den spreds snabbt till Norden och kom att inspirera liknande debatter i både Sverige och Danmark..$^{30} \$ 175$, den paragraf som som kriminaliserade homosexualitet i Tyskland, löd: "Onaturlig otukt, mellan personer av manligt kön eller mellan människa och djur, ska straffas med fängelse; ett straff som innebär förlorandet av medborgerliga rättigheter kan också tilldömas." ${ }^{31}$ Paragrafen är som synes strängare än den svenska motsvarigheten och skiljer sig också genom att den bara omfattar män. Paragraf 175 hade länge va- 
rit omtvistad i Tyskland och händelserna i Eulenburgaffären gjorde saken akut. Magnus Hirschfeld och hans Vetenskapligt-HumanitäraKommittén lierade sig med den politiska vänstern för att avskaffa paragrafen - andra politiska krafter ville utvidga den till att även omfatta kvinnor. 1909 publicerade lagkommissionen ett förslag om att göra paragrafen könsneutral.

De tyska kvinnoorganisationerna var inte eniga i sin reaktion. Den enda som tog ställning mot förslaget var Helene Stöckers Förbundet för mödraskydd och sexualreform, en organisation som Stéenhoff hade nära förbindelser med. ${ }^{22}$ Stöcker och andra som kritiserade förslaget ville förhindra att kvinnor som levde tillsammans eller som offentligt visade ömhet för varandra skulle kunna misstänkliggöras och i värsta fall åtalas. De lyfte fram sociala, ekonomiska och praktiska förklaringar till att kvinnor valde att leva tillsammans, men de anförde också känslomässiga skäl som kvinnors större behov av närhet och ömhet. Debattörerna skrev fram vänskap som ett gott alternativ för kvinnor när ett äktenskap inte kunde förverkligas och de framställde det som självklart och oklanderligt att kvinnor sov i varandras armar om nätterna. En av dem försvarade till och med sex mellan kvinnor - så länge kvinnorna inte var homosexuella vill säga. ${ }^{33}$ Intimitet mellan kvinnor mättes alltså med helt andra mått än den mellan män. Resultatet av debatten blev att paragrafen fanns kvar oförändrad.

De viktigaste argumenten som framfördes av Helene Stöcker och andra radikala feminister i denna debatt återfinns också i Stéenhoffs drama. Vänskap och kärlek mellan kvinnor är något för individen bra och för samhället oförargligt - så länge den inte går över gränsen till det förbjudna. Det fina i kråksången var att gränsen för det tillåtna var så generöst tilltagen att ingen kvinna rimligen skulle ha något att frukta från de rättsvårdande myndigheternas sida så länge hon i övrigt uppförde sig som hon förväntades göra.

Huvudpersonen i Kärlekens rival är Helena Grip, en vacker och välbärgad änka. I hennes hus umgås doktor Ejnar Lund, en karaktär som fungerar som något av en sanningssägare i dramat, och notarien Sverker Esbjörnsson, dramats skarptungade lustigkurre. En gissning är att hans rollkaraktär starkt bidrog till pjäsens popula- 
ritet. I huset finns också Irene Larsson, Helena Grips fosterdotter, tillika hennes innerligt avhållna väninna. Helena älskar Irene över allt annat och vill ha henne hos sig för resten av livet. Det är en svärmisk men ickeerotisk vänskap mellan en äldre och en yngre kvinna, en relation som har stora likheter med den som Dauthendey hade skildrat i Ny kärlek. Problemet är att Irene har förälskat sig i en ung man och känner sig mer och mer kvävd av Helenas pockande ömhetsbetygelser. Konflikten inom denna triangel utgör pjäsens dramatiska kärna och runt den finns andra kärlekskonstellationer som på olika sätt berikar idédiskussionen.

Helena Grip beskriver sina känslor för Irene så här: ”Du rör mig djupt. Det är ingen förklaring, men det är så."34 "Jag känner också, att det är nog med en vän som du för att livet åter skall bli ljust och rikt." (29-30) "Du kan inte jämföras med någon." (30) "Förlorar jag dig, så kan jag inte leva." (32) Känslorna är varma, intensiteten stor, men det är ändå en bit kvar till den gräns som går mellan det tillåtna och det förbjudna.

Människorna runt omkring dem vet inte riktigt hur de ska förstå relationen, men de uppfattar den hur som helst som alltför svärmisk. "Men fru Grip älskar henne, ja det är inte överdrivet sagt, att hon dyrkar henne. Och det brukar inte vara fallet med en vanlig skyddsling", säger doktorn. (10) "Jag tycker Helenas tillgifvenhet är nästan sjukligt stor", säger hushållerskan, medan notarien talar om "fallet Grip" och ber doktorn att han i egenskap av "dårhusläkare" ska skilja de båda kvinnorna åt: "Ni är hennes läkare. Och så har Ni asylen bakom Er, som ger auktoritet." (10, 20) Men doktorn går inte in på det. Till skillnad från så många andra läkare i tidens litteratur, som fick utslunga förmenta sanningar om det mesta, drar han sig ödmjukt tillbaka:

Jag beklagar, herr Esbjörnsson, men jag kan inte räcka Er den hjälpande hand, Ni ber om. Det går alldeles utanför min uppgift som läkare. Till motsats mot Er anser jag mig alls inte som mina medmänniskors förmyndare. Om fru Grip vill skämma bort fröken Larsson, det har jag sannerligen inte med att göra. (22) 
Relationen mellan Helena Grip och Irene Larsson går utöver det av omgivningen önskade, men inte så långt som till erotik. Med lite god vilja går det att baxa in Helenas känslor för Irene i det som kallas "vänskap". Helena inser att deras relation riskerar att bli misstänkliggjord, men vill inte tala om för Irene vad de outtalade anklagelserna egentligen handlar om. I stället försvarar hon de egna känslorna:

FRU GRIP:

Ofta har jag gått till rätta med mig själv och frågat, om min gränslösa tillgivenhet för dig kan vara orätt.

IRENE:

Hur skulle den kunna vara det?

FRU GRIP:

Den skulle kunna vara förkastlig, om den i sig hade något orent. Men den har inte det. - Du förstår inte nu min tankegång. Den är dig alltför främmande. Du är för ren för att fatta den.

IRENE:

Kanske du vill förklara den för mig?

FRU GRIP:

Nej, varför dröja vid sådant som är utan värde för oss. Är det till exempel orent att trycka en ros mot sin kind? Eller att stryka sin älsklingshund över hjässan? Om man har en fågel och värmer den i sin hand, är det sinnligt? Eller att trycka ett barn i sin famn? All tillgivenhet blir då fläckad och oren. De skönaste känslor bli förnedrande. (32-33)

Helenas försvar för intimiteten mellan dem bygger på att relationen är sinnlig utan att vara erotisk. Den är "ren", inte "oren". Dessa förmoderna och religiöst färgade begrepp ligger bra i munnen på den rollkaraktär som utsäger dem, men ingår annars inte i författarens vokabulär. Detta försvar för samkönad intimitet dyker upp en gång till i pjäsen och finns med även i Stéenhoffs nästa drama om kärlek mellan kvinnor, men där är ordet "orent" utbytt till det mer moderna "orätt". ${ }^{35}$ Att försvara den samkönade intimiteten genom att kalla den "ren" är nog en effektiv retorisk strategi, eftersom den avväpnar motståndarlägret. Men samtidigt är den förrädisk, eftersom dramat 
i övrigt har udden vänd mot just den moralkonservativa diskurs som ordet "ren" är hämtat från. En "normalmänniska skall ha ett visst kvantum själ och ett visst kvantum kropp" (39), säger notarien, ord som nog står författarens egen uppfattning nära.

Längre fram liknar Helena deras förhållande vid det mellan Bibelns Saul och David, en liknelse som slår an både dramats huvudmotiv - samkönad kärlek - och dess grundkonflikt - triangeldramat. Den älsklige, unge David kallades till den tungsinte konung Saul för att muntra upp honom med sitt harpospel. "Så kom David till Saul och trädde i hans tjänst och blev honom mycket kär, så att han fick bliva hans vapendragare", heter det i Samuelsbokens berättelse. ${ }^{36}$ Men David slöt också ett vänskapsförbund med den tappre krigaren Jonathan, Sauls son. Vid hans död sjöng David en klagosång, som slutade med ord som ofta har citerats i homolitteraturen: "Jag sörjer över dig, du min broder Jonathan; mycket ljuvlig var du mig. Dyrbar var mig din kärlek, mer än kvinnokärlek." ${ }^{37}$

Idédiskussionen i Kärlekens rival aktualiserar tidens vanligaste föreställningar om samkönad kärlek men har en egenskap som gör den ovanlig: den är inte fördömande. De skarpaste replikerna, och de som troligen framkallade mest skratt hos publiken när pjäsen spelades, läggs i Helenas eller notariens mun. De representerar varsin ytterlighetsposition i idédiskussionen. Men det är doktorn som står för de tyngst vägande reflektionerna. Helena förklarar varför hon föredrar kvinnor framför män, medan notarien för att skilja kvinnorna åt tar till en standardteori om homosexualitet, den om degeneration: Vissa släkter har blivit så överkultiverade att de har förlorat kontakten med "naturen" - heterosexualiteten - och riktar sina känslor till det egna könet. Han talar också om "urartning". Men när han gör det blir han näpst av doktorn: "Notarien rör sig med lekmannens djärvhet på ett område, där han inte är hemma." (71)

Doktorn motsäger såväl Helena som notarien när han tycker att de låter tankarna flyga alltför långt i den ena eller andra riktningen. När Helena förklarar att kvinnorna har börjat vända sig bort från männen på grund av deras dubbelmoral undrar doktorn förskräckt om hon hyllar "- könshatet?” (73) Det gör hon nu inte, men hon resonerar på samma sätt som Dauthendey gör i Ny kärlek och 
menar att kvinnorna, precis som männen genom historien alltid har gjort, behöver vänner av sitt eget kön. "Då kunde det olyckliga kvinnosläktet till slut finna sällhet hos sig själv. Det blev en världsbefrielse." (75) Doktorn ger henne rätt:

På många sätt trevar människosjälen efter räddning från melankoli. Naturens drift till självbevarelse tar olika uttryck. En stor vänskap har mer än en gång räddat känsliga varelser från förtvivlan och undergång. (Till notarien) Därför bör man vara ytterligt försiktig i sina omdömen. Man får inte misstänkliggöra vänskapen och därigenom förhindra det goda den kan uträtta. Överhuvud taget får man inte handskas med det psykiska för hårdhänt. Man kan inte dissikera växter med hammare och hovtång. (75)

Denna passage kan ses som ett av pjäsens många korrektiv i förhållande till den samtida retorik som använde grova språkliga tillhyggen när det talades om kvinnors samkönade relationer. Ord som inte var konstruerade för att förstå utan för att förstöra.

Notarien, som i själva verket är djupt förälskad i den unga änkan, erkänner att hans kritik mot kvinnornas relation egentligen handlar om hans egen svartsjuka. Han vill helt enkelt att de ska älska honom och inte varandra. Därpå skiftas följande repliker:

\section{NOTARIEN:}

Fru Grip, Ni tvivlar på mannens lyckliggörande, förädlande uppgift. Det är ett stort socialt brott. Att inte tro på mannen, det är att inte tro på gud. Det är hädelse. Det undergräver statens bestånd. FRU GRIP: (småler)

Vi har inga lagar ännu om hädelse mot mannen. Men vi får väl, när ni kommer till makten.

NOTARIEN:

Ack vore vi där! - En kvinna föredrar en kvinna - - Det är förmätet - Det är en utmaning - - O vad Ni retar mig som karl - (Sjunker ihop) Och vad jag dyrkar Er - - (75-76)

Notariens repliker är skämtsamt menade, även om det finns allvar 
bakom det mesta han säger. Hans oro över att kvinnorna inte dyrkar männen tillräckligt mycket framkallar skratt, men denna oro framfördes ju faktiskt på fullt allvar av åtskilliga skribenter i samtiden, till exempel av Ellen Key. Hon brukade tala om kärleken mellan man och kvinna i religiösa termer. Gång efter annan kritiserade hon kvinnorörelsekvinnorna för att inte alltid vara tillräckligt entusiastiska inför heterosexualiteten, och hon varnade för den katastrof som skulle inträffa om kvinnorna skulle intressera sig mindre för männen och mera för varandra. ${ }^{38}$

Helena menar att männen begär kvinnorna bara rent sexuellt, utan att i djupare mening älska dem. ”Tror Ni inte vi känner, att vi inte är omtyckta, om vi också är begärda. Om kvinnan vill bereda er njutning, då blir Ni artig och älskvärd, för att strax därpå förakta oss dubbelt." (85) Män tycks helt enkelt föredra att umgås med andra män. Hon beskriver den manliga homosocialiteten så här:

Er antipati /mot kvinnorna/ är evig. - Ni tycker däremot om varandra. I litteraturen gråter Ni varandras tårar. Ni torkar varandras ögon. Ni jollrar långa, ömma fraser, som ser ut som smekningar om varandras synder och laster. Ni har med ett ord sympati för varandra. Men ni känner solidariskt mot kvinnan. Och så tror $\mathrm{Ni}$, att Ni kan göra oss lyckliga? (85-86)

Och lite längre fram:

Lika så visst som männen i tidernas början gjorde gud maskulinum, lika så visst tror jag, att di blott dyrkar sig själva. Allt upphöjt tänkte ni er som en man. Där ser Ni genast den bristande sympatin. Ni satte er egen bild i skyn att tillbedjas. Vad är "vår herre" annat än den manliga egenkärlekens sigill på universum? Vad är er kärlek annat än själviskhet? (86)

Helena är på intet sätt författarens språkrör. Hennes kritik mot den androcentriska kulturen sammanfaller ibland med den som återfinns i Stéenhoffs socialreformatoriska texter, men hon har också åsikter som går på tvärs mot författarens. Helena är till exempel 
fyrkantigt fientlig mot de heterosexuella kärleksrelationer som finns i hennes närhet: "Det är sorgligt nog att di, som är gifta lever som gifta. Men att di, som inte är gifta gör det, är mycket illa”, säger hon (127), en replik som givetvis är tänkt att framkalla skratt. Varken dramat eller författarinnan delar Helenas sexualfientlighet och den finner heller inget stöd hos väninnan. Irene är ju kär i en man och upplever förhållandet med Helena som kvävande: "Hennes 'renhet' och hennes 'oskuld' - det är så tomt för mig, det är som bara luft. Jag dras till glöd och berusning, till manlig kärlek, till allt det där som hon föraktar." (106)

Helena är dramats centralgestalt och motorn i idédiskussionen, men den karaktär som nog kommer närmast rollen som författarens språkrör är den vänlige doktorn. Hans ord om kärleken mellan man och kvinna utgör dramats (hetero)utopiska moment:

Kanske bör kärleken icke upphöra. Om kvinnor och män drömmer, väntar, hoppas allt av det motsatta könet och icke av sitt eget, går kanske verkligheten i drömmarnes spår. Generationer efteråt få kanske skörda, vad de föregåendes längtan sått. Tro inte att jag har några teorier om detta. Man kan aldrig vara nog försiktig. Det är bara ett hugskott. - Mannen blir kanske till slut, vad kvinnan i sina bästa stunder drömt honom vara och vice versa. Men då får inte män sluta att drömma om kvinnor och kvinnor om män. Inte upphöra att tro, att lyckan ligger hos det motsatta könet, inte hos ens eget. Det är tron det kommer an på. (99)

Doktorn liknar många andra doktorer i den samtida skönlitteraturen genom att det är han som framför de övergripande tankarna om den mänskliga naturen, men han skiljer sig från andra genom att han inte gör anspråk på att besitta Sanningen. Han reducerar sina egna tankar till "hugskott". Hans sätt att avvisa alla stora kunskapsanspråk är en viktig aspekt av pjäsens radikalitet. En annan är att den över huvud taget tar upp samkönad intimitet och en tredje att pjäsen så passionerat försvarar kvinnors kärlek till kvinnor, även om försvaret inte får stå oemotsagt. Villkoret för dess existens är att den inte får vara erotisk och inte stå i konflikt med heterosexualiteten. 
Stéenhoff tycks på många sätt ha gått Key till mötes i frågan om hur man får och inte får skriva om kärlek mellan kvinnor. Några "abnorma" inslag finns det knappast i pjäsen och den "galne karlens moment" är borttaget. Stéenhoff har också sett till att "få in på scenen den friske, starke unge mannen" och återinstallerat heterosexualiteten som norm. Dessutom har hon lagt in en utopi om heterokärleken som en historisk utvecklingskraft, vilket Key så gärna ville tänka sig. I förhållande till sin position tolv år tidigare verkar det som om att Stéenhoffs åsikter, eller i alla fall hennes sätt att förvalta dem litterärt, kan ha förändrats. Ändå var Key inte nöjd. Stéenhoff borde ha tagit ytterligare ett steg i riktning mot heteronormalisering. Key tackade för Kärlekens rival,

som är mycket tänkvärd. Endast tror jag att du borde satt det medvetna upproret i själfmordets ställe? Vår tid har ju mycket av denna sjukdom och dess djupaste orsak är: att kvinnan så ofta förgäves hos mannen sökt det själiska sambandet, utan vilket nutidskvinnan ej finner kärleken stor nog? ${ }^{39}$

Key vänder sig mot att Irene vill ta livet av sig på grund av konflikten mellan kärleken till kvinnan respektive mannen. Hon borde i stället ha revolterat mot kvinnan till förmån för mannen. Här, som så ofta i tidens homofoba retorik, framskymtar tanken att samkönad kärlek bygger på att den ena parten har makt över den andra. Att det skulle finnas ett slags homoerotiskt maktcentrum någonstans varifrån det utgår ett hot mot heterosexuella ungdomar brukade också ingå i detta sätt att tänka.

Uppenbart hade pjäsen trots allt kvar en del av sin normativitetskritiska potential. Det var inte bara Ellen Key som tyckte så. Kritikern Gertrud Almqvist skrev så här i Idun 1912:

Frida Stéenhoff har i sitt skådespel berört ett problem, hvarmed vi möjligen snart nödgas räkna: den kvinnovänskap, som tangerar gränsen för det erotiska området eller öfverskrider den, men hennes inlägg går knappt till djupet af den allvarliga frågan. Det fordras för öfrigt en annan auktoritet än den litterära eller social- 
reformatoriska, nämligen psykiaternas, för att giltigt behandla olyckliga och ensamma kvinnors surrogat för kärleken. Unga åtråvärda änkor och bedårande adertonåringar äro i alla fall inte de offer, som kunna tänkas allvarligast utsatta för försökelserna från vänskapen som "kärlekens rival". ${ }^{\circ}$

Enligt Gertrud Almqvist tycks det vara psykiatriker som ska hantera samkönad intimitet, inte konstnärer, alltså precis den tanke som kritiseras i dramat. På ett raljerande sätt viftar hon undan tanken att kvinnor som förmår att attrahera män skulle kunna föredra varandra. Nej, kvinnokärlek är ett surrogat för heterosexualitet, något som sjuka, halvgamla och fula kan ta till om de inte får tag på en karl. Sett i den belysningen framstår dramat trots allt som radikalt för sin tid. Eller menar recensenten i själva verket något annat? Kanske att temat hanteras för ytligt? Även den tolkningen är fullt möjlig. Almqvist skulle, som vi ska se längre fram, nämligen själv komma att skriva om kärlek mellan kvinnor på ett mycket intressant och nyanserat sätt. Det skedde i romanen I tolfte timmen 1928. Men då skrev hon väl att märka, precis som Stéenhoff gjorde i Kärlekens rival, under pseudonym.

\section{Lågornas rov}

1928 återvände Stéenhoff till motivet kärlek mellan kvinnor en sista gång. Hon arbetade om Kärlekens rival till en novell eller roman - hon använde olika genrebeteckningar i olika manuskript - som uppenbart var avsedd för publikation men som aldrig blev mer än ett manuskript. ${ }^{41}$ I förordet till texten står det att den nya versionen "rör sig med samma personer och samma problem" som den tidigare, "men med nya synpunkter och episoder". Den nya texten har, precis som den förra, hämtat titeln från avslutningsrepliken i Kärlekens rival:

FRU GRIP:

En stor vänskap och - kärleken - ryms inte samtidigt i ett människohjärta. 
NOTARIEN:

Kanske, med frihetens hjälp. - Men om vänskapen skall bli kärle-

kens svartsjuka rival, blir det stackars hjärtat ett lågornas rov. (141)

"Lågornas rov" skrevs med anledning av att det i Stockholm just då gick en fransk pjäs som behandlade samkönad kärlek, Eduard Bourdets Den fångna. Här skildras passionen mellan två kvinnor genom den effekt den har på deras män. Ordet "vänskap" är bara en mask för att dölja de passioner som i varje fall männen inte förstår sig på. ${ }^{42}$ Kvinnorna uppträder aldrig på scenen tillsammans och den ena av dem är närvarande endast genom en bukett violer, som har en oemotståndlig dragningskraft på den andra. Vad kvinnorna tänker får vi aldrig veta, men man förstår att det handlar om en erotisk passion och att det är den ena av dem som är drivande medan den andra försöker fly. De äkta makarnas kärlek betyder ingenting för dem. Heterosexualiteten triumferar inte.

Stéenhoffs text är tänkt som ett slags replik till den franska, och samtidigt ett försvar både för Keys förord till Dauthendeys bok och för den egna pjäsen Kärlekens rival. I förordet till novellen står det:

I pressen påvisades vissa likheter mellan de båda dramerna: På bägge hållen voro de äldre väninnorna utomordentligt intagande och harmoniska personligheter, på bägge hållen talades om fångenskap - "den fångna", "känna sig som i fängelse" - samt i båda styckena hette den yngre hjältinnan Irene. ${ }^{43}$

"Lågornas rov" bygger delvis på samma historia som Kärlekens rival, men idédiskussionen är nu mer explicit. De förbjudna känslorna nämns vid sina rätta (?) namn och samtida könspolitiska idéer arbetas in i dialogen. I Kärlekens rival var det bara den ena i kvinnoparet som var förälskad i en man, men i "Lågornas rov" räddas båda kvinnorna över till heterosexualiteten. Alldeles i slutet av berättelsen tänds nämligen kärlekens låga mellan Helena och notarien, som nu kallas Sverker. Det visar sig att han - lite otippat för den som har Kärlekens rival i färskt minne - är den Nye Man som Helena, den Nya Kvinnan, så länge har saknat. Stycket ger heterosexualite- 
ten företräde, utan att därför vara antihomosexuellt. Kärlek mellan kvinnor framställs som ett surrogat, men ett gott sådant, så länge män inte lever upp till kvinnornas standard.

Notarien/Sverker visar sig alltså vara en modern man. "Han hade läst Freud och Adler. Adler hade med lätthet gjort honom till feminist - därför att Helena var feminist." Att en manlig hjälte kallas för "feminist" har nog inte många motstycken i den tidens svenska litteratur. Om något.

Liksom i Kärlekens rival skvallras det om Helena och Irene och det handlar inte om något vänligt småprat. Helena har fått anonyma skrivelser med beskyllningar om "perversitet". ${ }^{44}$ Hushållerskan säger till Sverker: "I ditt ställe skulle jag aldrig drömt om att bli kär i Helena. Hon är en 'tvättäkta spinster"', varpå han svarar: "Det är en motsägelse. Man kan inte på en gång vara förtjusande och spinster." Hans svar ska troligen uppfattas som ironiskt eller humoristiskt, för läsaren vet redan att han är djupt förälskad i Helena. Klart är att ordet "spinster" är nedsättande. Ett par decennier tidigare hade "oskuld" och "renhet" varit användbara retoriska verktyg för den som ville leva i en samkönad relation, men nu hade orden fått nya innebörder och en negativ värdeladdning. Talet om "oskuld" var inte längre gångbart i en modern diskurs. ${ }^{45}$ Helena försvarar sina känslor för Irene med följande passage som känns igen sedan Kärlekens rival:

Ofta har jag gått till rätta med mig själv och frågat om min stora tillgivenhet för dig kan vara orätt. Men då skulle själva förmågan att hålla av vara orätt? Och allt sinne för skönhet och älsklighet vara ett sinnligt brott? Om man trycker en ros mot sin kind? Om man stryker sin älsklingshund över hjässan? Eller värmer en fågel i handen? Är det sinnlighet? För att inte tala om, när man trycker ett barn i sin famn. All tillgivenhet blir fläckad och oren, de skönaste känslor blir förnedrade, när männen talar om sinnlighet.

Den fråga novellen kretsar kring är huruvida relationen mellan Helena och Irene är erotisk eller inte. Särskilt intresserad är Sverker, eftersom han ju är förälskad i Helena. "Fru Grip älskar dig men hon behöver dig inte. Hon är frigid", säger betjänten till honom. 
"Frigid, upprepade Sverker stelt. Är hon abnorm?" Männen pratar om vad dessa ord kan tänkas innebära. "Frigiditet" var ett ord som i den samtida diskursen brukade användas för kvinnor som inte responderade bejakande på en mans sexuella aktiviteter, men i den här dialogen ges det en helt annan innebörd. Orsaken till kvinnors frigiditet ska inte sökas i den enskilda kvinnans psykologiska och fysiologiska natur, utan i hur relationen mellan kvinnan och mannen ser ut. För en kvinna som säljer sig, vare sig det nu sker till en man i ett äktenskap eller till flera i reguljär prostitution, kan frigiditet vara ett sätt att skydda sig. De båda männen i dialogen menar dessutom att båda könen kan och bör vara erotiskt oberörda i vissa situationer, för man ska inte tända på allt och alla - till exempel inte på sina patienter, nära släktingar eller barn.

För att försöka få klarhet i frågan om varför Helena är så intresserad av väninnan och så ointresserad av honom själv, tar Sverker med Helena på teatern. De ser Bourdets Den fångna, en pjäs som spelades i Stockholm vid den tid då Stéenhoff arbetade med texten och som den är en replik på. "Helena och Sverker sutto i teatersalongen. Den var ej helt fylld men stämningen var mättad av förväntan. Publiken trodde sig genom tidningarna veta att pjäsen var homosexuell." Helena är skeptisk till om stycket kommer att slå. "Stockholm är inte rätt forum för könspsykologisk dramatik. Här uppskattas erotik och sensualitet, rätt och slätt, det är något helt annat." Hon syftar förstås på heterosexuell erotik. Eller är det ändå så att tiderna håller på att förändras? "Men nu lever vi i en erotisk kristid, eller hur?" Repliken är Helenas.

Sverker och Helena funderar över de motsägelsefulla sexuella krav som kvinnor ställs inför. Å ena sidan föraktas den kvinna som ger sig åt en man utan att vara gift, hon förlorar sitt sociala värde och blir paria. Alltså borde kylighet vara något att sträva efter. Men detta är heller ingen accepterad position eftersom heterosexualitet är obligatorisk för den som vill gälla som frisk och normal. Att inte älska en man ses hos en kvinna som ett uttryck för abnormitet. I ämnet kärlek mellan kvinnor kommer de fram till följande:

- Sinnlig eller osinnlig, invände Sverker, det kvittar lika. Olyckan 
är att männen blir överflödiga. Jag måste hålla på männens lycka, jag är part i målet. Homosexualitet i vanlig mening finns naturligtvis också bland kvinnor, det garanteras av vetenskapen.

- Men jag tror, sade Helena, att idealvänskap förefinns i mycket större utsträckning. Och den är en välsignelse. Millioner kvinnor skulle bli totalt isolerade utan dylik vänskap.

Sverkers kritik mot kvinnokärleken från manssynpunkt har tonats ned rejält i förhållande till hur den såg ut i Kärlekens rival. Nu har också han knuffat ner mannen från sin gudaposition. Det är Sverker som konstaterar att erotik mellan kvinnor faktiskt existerar, medan Helena föredrar att tala om vänskap. Läsaren vet att hennes förhållande till Irene inte är sexuellt, men det gör inte Sverker och det är detta han försöker få klarhet i. För att förklara hur hon ser på problemet tar Helena upp Ny kärlek och förordet av Ellen Key (som nu var död sedan ett par år):

För många år sedan utkom en bok som hette "Ny kärlek", av en tysk författarinna: Elisabeth Dauthenday. Den hade ett allvarligt företal av Ellen Key. Det var därför jag kom att läsa boken. I tyska pressen hade den mottagits seriöst, i den svenska övervägande skämtsamt.

Beskrivningen av mottagandet av boken känns igen från den tidigare diskuterade artikeln om Key och Dauthendey. Men Stéenhoffs egna tankar är här lagda i munnen på Helena som kommenterar läsningen av Dauthendeys roman så här:

- "Ny kärlek" gjorde ett djupt intryck på mig, sade Helena. Den ändrade min syn på en massa saker. Kvinnor har behov av sympati. Varför skulle de inte ägna varandra sina sympatiska känslor när de inte får slösa dem på män? Elisabeth Dauthenday tänkte sig sin nya kärlek helt begränsad till det andliga området, således fullkomligt skild från perversitet i rent sexuell bemärkelse. Hon önskade den ej blott som ett tröstande ersättningsmedel för kvinnorna själva utan också som ett kampmedel att därmed fram- 
tvinga den "nye" mannen. Det ligger mycket lidande bakom en sådan tankegång.

Här skiljs, för det första, den andliga intimiteten från den sexuella och det är bara den förstnämnda som försvaras. För det andra ses kvinnors vänskap som ett surrogat när kärleken till männen är omöjlig och för det tredje är den politisk och interimistisk, ett medel för att tvinga männen att ändra sig. Samtalet fortsätter och tar nya vägar. Det är Helena som börjar:

- [Key] ville anbefalla boken till begrundande. Det var en kulturgärning som allt vad hon gjorde. Hon ville rikta uppmärksamheten till ett försummat område. Hon tyckte kvinnorna skulle klargöra sin åsikt för eller mot en tidsströmning som undgår analys därför att den med flit lämnats i det fördolda. Hur många fördomar måste inte bort för att kännedomen ska ökas om människans möjlighet till lycka?

- Jag vet, sade Sverker, att antikens kvinnor gav varandra rådet att söka lyckan hos varandra.

- Det rådet har nog givits och mottagits under alla högre kulturskeden. För då tvingar förhållandenas makt män och kvinnor ifrån varandra. Varför inte unna alla levande väsen så mycket tillfredsställelse som möjligt? När dom inte skadar någon annan?

Kärlek mellan kvinnor har funnits i alla kulturer där män och kvinnor inte längre kan mötas. Surrogatteorin alltså. Men samtidigt sägs ju att den samkönade kärleken kan vara något gott för individen och att den inte skadar någon annan. Längre än så i försvaret av den samkönade kärleken var det inte många som brukade gå i offentliga sammanhang vid den här tiden.

Historien slutar med att Irene försöker dränka sig, sliten som hon är mellan vänskapen för Helena och kärleken till en man, men hon blir räddad av Sverker. Han visar sig vara den Sanne Hjälten och Rätte Älskaren. Slutet gott allting gott. Stéenhoff följde här samma mönster som så många andra författare skulle komma att göra långt, långt fram på 1900-talet: Om man skrev om samkönad kärlek, 
så måste man se till att heterosexualiteten återställdes som norm på slutet. Detta kunde, som här, ske genom att den Rätte Mannen plötsligt dyker upp, eller genom att den ena eller båda kvinnorna går under genom galenskap, droger, brott eller sjukdom och död. Karin Smirnoff hade i dramat Ödesmärkt (1924) återställt den heteronormativa ordningen på samma sätt; den tragiske, homosexuelle hjälten dör på slutet.

Men den kommentaren är anakronistisk och inte avsedd att förringa Stéenhoffs insats på det här området. För om man jämför hennes skrivande om samkönad kärlek med vad som tidigare hade publicerats på svenska, får man konstatera att hon var extremt tidigt ute med att försöka behandla motivet på ett öppet och nyanserat sätt. Så tidigt att den första av dessa texter troligen blev lågornas rov, medan ett par av de senare i stället blev rov för skrivbordslådorna.

\section{Trettio år av samkönad kärlek}

Mycket hade hänt under de nära trettio år som gått mellan Stéenhoffs första och sista text om kärlek mellan kvinnor. När "Det moderna Lesbos" skrevs var ämnet tabubelagt. Det var i praktiken omöjligt för en skönlitterär författare i Sverige att skriva både öppet och nyanserat om det. Men forskningen intresserade sig alltmer för frågan, och som redan nämnts utkom en rad böcker i ämnet på 1910-talet. Sigmund Freud skrev sina viktigaste sexualteoretiska verk under denna tid. 1914 kom Magnus Hirschfelds mäktiga Die Homosexualität des Mannes und des Weibes, ett verk som i grunden förändrade synen på homofrågan för dem som seriöst funderade över den. Tidigare hade Hirschfeld också publicerat Berlins Drittes Geschlecht (1904) och Die Transvestiten (1910). Alfred Adlers Das Problem der Homosexualität utkom 1917 och två år senare Anton Nyströms Om homosexualitet och hermafroditi. Man kan rentav tala om en homovetenskaplig hausse.

På 1920-talet kom också en rad skönlitterära verk som flyttade fram positionerna. Karin Smirnoffs drama, en manligt homosexuell passionshistoria, falsifierade många av tidens fördomar. Även Alma Söderhjelm skildrade i romanerna Kärlekens väninna (1922) och 
Den flygande holländaren (1923) manlig homosexualitet. Agnes von Krusenstjerna vidgade genom Tony-trilogin (1922-1926) utrymmet för hur man kunde skildra samkönad kärlek, och David Sprengels svenska utgåva av Denis Diderots Nunnan (1925) visade att motivet funnits i litteraturen sedan långt tillbaka i historien.

År 1928 publicerades en rad klassiska lesbiska romaner i olika delar av Europa. I Sverige presenterade Victor Svanberg sin avhandling Novantiken i Den siste atenaren, där han lyfte fram det homoerotiska motivet i Viktor Rydbergs författarskap, något som sände ut en chockvåg i det litterära Sverige. Samma år publicerade också Stéenhoffs kritiker från 1912, Gertrud Almqvist, en intressant roman med lesbiskt motiv, visserligen under pseudonym, men ändå. Samkönad kärlek var fortfarande en ytterst kontroversiell fråga, men inte riktigt så hårt tabuerad som den en gång hade varit. I vissa konstnärliga kretsar var den faktiskt hipp.

Kanske var det inte längre ämnet som gjorde att "Lågornas rov" aldrig fullbordades. Under de tre decennier som hade gått sedan "Det moderna Lesbos" skrevs hade andra författare hunnit i kapp Frida Stéenhoff. Men sin pionjärstatus hade hon då hunnit säkra för länge sedan. När historien om kvinnors kärlek till kvinnor en gång skrivs, så kommer hennes modiga försök att få upp denna kontroversiella fråga på den litterära och politiska dagordningen att ha en given plats. 